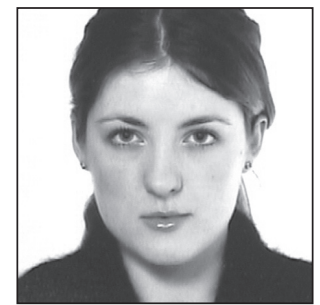

Annemari Õunpuu

Lawyer

Swedbank AS

\title{
The Shortcomings of Commercial-pledge Regulation and Need for Reform
}

\section{Introduction}

The roots of modern-day generic business security go back to 19th-century England, where the case law for the first time recognised a universal non-possessory charge over all present and future assets of a company $^{{ }^{*}}$. To this day, jurisdictions vary greatly in their approach to the 'universal pledge' of the company's assets. There are countries, such as Austria, that require a high degree of creditor possession and specificity, thereby ruling out the possibility of a general pledge and a pledge on future assets ${ }^{{ }^{2}}$. At the other end of the spectrum are common-law countries such as England and the United States. In England, the creditor has the possibility of a truly global security right for all assets of the company, both present and future, real and personal property ${ }^{*} 3$. The United States 'floating lien' is of identical nature, allowing for a security right over present and future movables, with the difference from its English counterpart being that the US version can be given by companies and individuals alike whilst the English floating charge may be granted only by companies. Also, in the United States there are separate state regimes for real property ${ }^{*}$. The availability of a general pledge on a company's assets seems to go hand in hand with the availability of general debtorindexed registries and notice-filing systems as opposed to strictly asset-title registries. The wider the scope of the general pledge on company assets, the greater the interest in minimising the possibility of the same asset being pledged via a specific fixed security right without the knowledge of the general pledge holder.

The Estonian Commercial Pledges Act took effect on 1 January $1997^{* 5}$ and in its core aspects has remained the same to this day. From the early days of its creation, the commercial pledge has received the treatment of a pledge non grata. It has been called a 'threat to trade credit"*6, a 'peculiar phenomenon' that exists in parallel with 'decent securities', and 'an outsider' to the specificity system for reason that it violates

E. Ferran. Principles of Corporate Finance Law. Oxford: Oxford University Press 2008, p. 369.

2 W. Faber, B. Lurger. National Reports on the Transfer of Movables in Europe - Volume I: Austria, Estonia, Italy, Slovenia, European Legal Studies. Munich: Selliers, European Law Publishers 2008, p. 182 DOI: http://dx.doi.org/ 10.1515/9783866537019.

3 P.R. Wood. Comparative Law of Security Interests and Title Finance, Vol. 2 in the Law and Practice of International Finance Series. London: Sweet \& Maxwell 2007, p. 6-011.

4 Ibid., p. 6-015.

5 Kommerstpandiseadus. - RT I 1996, 45, 848; RT I 21.06.2014, 31 (in Estonian). English text available at https://www. riigiteataja.ee/en/eli/527012015013/consolide (most recently accessed on 22.3.2015).

6 M. Wenckstern. Ekspertiis Eesti kommertspandi seaduse eelnõule (Expert Assessment to Draft Act of the Estonian Commercial Pledge Law), 31.10.1995, via P. Varul et al. Asjaõigusseaduse kommentaarid (Law of Property Act, with Commentary). Tallinn: Juura, p. 368 (in Estonian). 
the principle by which a security right can extend only to a specific asset or right ${ }^{*}$. No doubt, such views have been heavily influenced by the approach of the Germanic group of countries (Germany, Switzerland, and Austria) relying on the doctrine of specificity and using retention of title and fiduciary transfers as substitutes for non-possessory pledges ${ }^{*}$ - although, on closer examination, the latter legal mechanisms can be said to be a pure matter of form for escaping pledge possession"*"

On 1 January 2015, the Commercial Pledges Act reached the age of majority. In light of criticism by academics, recent Supreme Court practice, and international developments, it is justified to ask whether the concept of the commercial pledge needs revision.

\section{The scope of the commercial pledge}

\subsection{The aim of the 'universal pledge'}

International organisations such as United Nations Commission on International Trade Law (UNCITRAL) and European Bank for Reconstruction and Development (EBRD) recommend that the law provide for a security right that secures all types of debts and extends to any type of asset, present or future, whether individually or in a pool of assets ${ }^{* 10}$. In the broadest sense, it would mean a global security for a global debt - an idea bound to create resentment in Estonia, as the Supreme Court has questioned the reasonableness of providing security for a global debt, so far, in the context of mortgages ${ }^{*}{ }^{* 11}$. It is also recommended for the security right not to limit the use of assets, as any possessory security right in the modern market economy would be self-defeating, requiring the debtor to assign the assets necessary for conducting the entity's business $^{* 12}$. The purpose of the above-mentioned recommendations is to suggest a system that could help companies to 'maximize the extent to which they can utilize the value inherent in their movable assets to obtain credit" ${ }^{*}$.

The answer to the question about the scope of the commercial pledge depends on what one sees as the main aim of the universal pledge and its role in achieving the purpose envisaged by the UNCITRAL. It is possible to enumerate four main functions of the non-possessory universal pledge.

Firstly, it is a security right enabling future assets to serve as security for the credit, without the need to amend the pledge agreement once the assets are produced or obtained. Objection to this aim usually is related to two factors: security granted for a debt existing today on assets acquired tomorrow diminishes the assets available to unsecured creditors, and security on future assets is a preference as it is granted for past debt ${ }^{* 14}$.

Secondly, it is a security right enabling the creation of a 'global pledge' on a company's assets by pledging the whole enterprise by means of a single agreement, without the need to pledge every group of assets or single item individually. Using a single security agreement instead of multiple individual agreements significantly reduces transaction costs. It has been claimed that in the event that the 'global pledge' can be enforced by an administrative possessory receiver (an official whose functions are similar to those of a bailiff or bankruptcy administrator), it allows the company to be managed as a going concern, preserving the

7 V. Kõve. Varaliste tehingute süsteem Eestis (System of Proprietary Transactions in Estonia), doctoral thesis. Tartu 2009 (in Estonian), pp. 246, 258, 333 .

$8 \quad$ P. Varul et al. (see Note 6), p. 369.

9 P.R. Wood (see Note 3), p. 6-017.

10 UNCITRAL Legislative Guide on Secured Transactions, United Nations 2010, Recommendation 17; EBRD core principles for a secured transactions law, Principle 7.

11 Along the lines of Germanic specificity doctrine regarding pledge objects, the Supreme Court has also emphasised that, although the law allows securing against both present and future debt, said right is not unlimited and an agreement by which a 'global debt' is secured by the pledge can be contrary to good morals in the extent that it fails to specify future debt or secures against all possible claims of the pledge holder, thereby limiting the pledgee's economic freedom and ability to cope in the future (Supreme Court rulings 3-2-1-104-08, of 5.11.2008, paragraph 19 and 3-2-1-64-12, of 29.5.2012, paragraph 27). The Supreme Court refers directly to the harmful effect of overcollateralisation, admitting at the same time that, in cases of companies, agreements on security for global debt are allowed for purposes of securing the so-called credit lines (see Supreme Court ruling 3-2-1-64-12, of 29.5.2012, paragraph 29).

12 EBRD core principles for a secured transactions law (see Note 10), Principle 2.

13 UNCITRAL Legislative Guide on Secured Transactions (see Note 10), p. 2.

14 P.R. Wood (see Note 3), pp. 6-007, 7-007. 
maximum value until the sale and enabling eventual sale of the company as a whole rather than in a piecemeal fashion that would destroy its value ${ }^{*} 15$. Although such a possibility existed for floating charge holders in England for some time, the relevant law was changed in 2003 to limit the appointment of the receiver to fixed charges only ${ }^{*} 6$.

The third function is to enable a pledge over assets for which there are neither special asset-title registries nor possibilities for other non-possessory pledges.

Fourthly, assets may be left with the debtor, allowing him to continue the use of his assets in the ordinary course of business.

The main aim with the existing solution for a commercial pledge clearly serves the third purpose: of grasping in its scope bulk assets that it would be difficult to pledge in any other way. However, the legislator has not been consistent on the question of the scope, as until 1994 the universal-pledge provisions in the Property Act also encompassed immovable property. The amendments made in 1994 excluded from the scope immovable and intellectual property and vehicles. The reasoning behind the amendments was to rule out possible competition between pledges - i.e., a commercial pledge as the universal pledge against a specific pledge in an asset-title register ${ }^{* 17}$.

In 2013, the Supreme Court found that from 1 July 2003 to 30 June 2011 the Traffic Registry did not comply with the requirements for a public register and that, therefore, it was not possible to register valid pledges of motor vehicles in the Traffic Registry. The Commercial Pledges Act excludes from the scope of commercial pledges those assets for which there is a possibility of having another class of registered security. Accordingly, from 1 July 2003 to 30 June 2011, there was no such possibility for motor vehicles; the scope of the commercial pledge during that period also extended to vehicles registered in the Traffic Registry. As of 1 July 2011, the scope of the commercial pledge is again narrower, for by that time the legislator had dealt with the publicity issues related to the Traffic Registry ${ }^{*}{ }^{18}$. The court practice confirms that the scope of the universal pledge is dependent on the existence and publicity of other 'pledge registries' available for movables. If the registry fails the publicity test, then, according to the opinion of the Supreme Court, the asset falls back to the scope of the commercial pledge.

The legislative developments and explanatory notes do not give clear guidance as to what the legislator has understood to be the main essence of the commercial pledge. The persons having the right to grant a commercial pledge have been limited to legal entities ${ }^{*}{ }^{19}$, which indicates that the pledge should maximise the possibilities of companies to receive credit. However, legislative amendments and court practice give no evidence that the commercial pledge was ever meant to be used to pledge the enterprise as a whole, nor that any thought would have been given to the concept of its interconnectedness with a universal business pledge preserving the value of the business as a going concern and selling of the enterprise as a whole, especially within reorganisation proceedings. The lack of consideration given to such interconnectedness is of no surprise, as the concept of business reorganisation is a relatively new phenomenon on the Estonian regulative landscape, with the Reorganisation Act having been adopted only in late $2008^{*} 20$. In consideration of the approach taken in England in limiting the powers of floating charge holders, it seems that the previously advocated success in allowing the floating charge creditor to appoint an administrative receiver to manage the business and enforce the charge (thereby allegedly maximising the returns) has been controversial and subject to abuse and, in consequence, should not serve as a role model.

The 'fluctuating scope' of the commercial pledge, dependent as it is on the publicity 'mistakes' made by the Estonian state with regard to registries of certain movables (such as vehicles), leaves creditors with lack of legal certainty and proves that the question of publicity of non-possessory pledges needs a systematic

15 Ibid., 6-0o8. See also M. Marinč, R. Vlahu. The Economics of Bank Bankruptcy Law. Berlin; Heidelberg, Germany: Springer 2012, p. 12 DOI: http://dx.doi.org/10.1007/978-3-642-21807-1 .

16 Insolvency Act 1986 as amended by the Enterprise Act 2002. Text available via http://www.legislation.gov.uk/ukpga/1986/45/ section/72A (most recently accessed on 24.3.2015). See also P. Hood. Principles of Lender Liability. Oxford: Oxford University Press 2012, pp. 564, 568-569.

17 P. Pärna, V. Kõve. Asjaõigusseadus. Kommenteeritud väljaanne (Law of Property Act, with Commentary). Tallinn: Juura 1996, p. 431 (in Estonian).

18 Supreme Court Civil Chamber ruling 3-2-1-133-13, of 11.12.2013, paragraphs 28-33.

19 In contrast to the United States, where a universal security right may be granted by both companies and individuals (subject to certain limitations set forth in consumer law).

20 Saneerimisseadus. - RT I 2008, 53, 296; RT I 09.05.2014, 2 (in Estonian). English text available at https://www.riigiteataja. ee/en/eli/510072014027/consolide (most recently accessed on 23.3.2015). 
approach. The fundamental question that the legislator needs to answer is whether the commercial pledge should continue serving the companies and their creditors as an additional security (a 'crutch' for situations wherein other pledge possibilities fall short) or should instead provide parties with flexibility in determining to what extent they want to utilise the assets for crediting purposes. In the latter case, the parties should be free to design the security package and decide on the scope of the pledge for each individual situation by limiting or extending the scope of the general pledge accordingly ${ }^{* 21}$.

\subsection{Narrow scope versus wide scope}

The question of scope cannot be separated from that of preference in cases of enforcement and insolvency, since the initial broad scope is said to be 'of little value if the collateral is diminished in insolvency, either by the priority of unsecured creditors (such as employees, taxes, reorganization costs, contracts and new money) or by a percentage cut from the collateral, or by enforcement delays" ${ }^{\text {"*2 }}$. The main argument for narrowing the scope of a commercial pledge is the protection of unsecured creditors against overcollateralisation of a single creditor. At the same time, limiting the use of future assets and assets that cannot be precisely identified as security for credit in one way or another increases the costs of the debtor, whether in the form of a higher interest rate or through costs related to cumbersome and legally uncertain schemes for use of future and bulk assets as security.

Although acknowledging its great importance, the present article does not deal with the issue of priority ranking in insolvency. It focuses, rather, on the initial scope of the commercial pledge. However, one general remark can be made on the interaction between the initial scope and its subsequent erosion within insolvency proceedings - namely, that the wider the initial scope, the greater the need for the priority and preference of other creditors. England, which has introduced one of the farthest-reaching universal security rights, has also introduced a system that would allow equalising the creditors in insolvency by creating the 'ring-fenced fund' as otherwise there would be nothing left for unsecured creditors. The mechanism basically takes some of the floating charge proceeds and distributes them to unsecured creditors ${ }^{*} 23$.

The scope of the Estonian commercial pledge at first glance appears rather wide, with the law stating that the pledge extends to all present and future movables. However, the law makes many exclusions from the scope: money (cash or on bank account); shares, stocks, promissory notes, or other securities; property on which it is possible to have another class of registered security over movables; property to which a mortgage established on the immovable before or after establishment of the commercial pledge extends; and property secured by a possessory pledge ${ }^{*} 24$. The real extent of the commercial pledge is thus mainly equipment, inventory, raw materials, livestock, and receivables. In theory, the practical value of the commercial pledge has been noted to lie in the possibility of pledging assets for which there are neither asset registries nor any other possibilities for a non-possessory security right, such as machinery and equipment ${ }^{* 25}$. In commercial practice in Estonia, the assets for which commercial pledges are used range from stock such as heavy metal components and fertilisers to food products, receivables, inventory, petroleum and petroleum products, and crops.

The reason for which the commercial pledge has not created that many problems in practice is seen in the fact that to this day its true nature and extent has not been understood and issues related to enforcement and bankruptcy are left open and unresolved ${ }^{* 26}$. The latter claim is supported by recent Supreme

21 According to the EBRD core principles for a secured transactions law, the law should support the operation of the secured credit market and provide the parties with flexibility to 'adapt the security to the needs of their particular transaction' without concentrating too much on the manner in which the transaction is structured (Principle 10).

22 P.R. Wood (see Note 3), p. 6-001. J.A. MacLachlan has referred to the bankruptcy test as the most fundamental tests for the strength of the security right, using the following words: 'Any security that will not stand up in case of insolvency of the debtor is only a trap for the unwary creditor. Of all the tests to which a security transaction can be put, bankruptcy is the most exacting. This is as it should be.' J.A. MacLachlan. The impact of bankruptcy on secured transactions. - Columbia Law Review 6o (1960) /5, pp. 593-609 DOI: http://dx.doi.org/10.2307/1120040 .

23 For the priority ranking in England, see P.R. Wood. Principles of International Insolvency, Vol. 1 in the Law and Practice of International Finance Series, 2nd edition. London: Sweet \& Maxwell 2007, p. 11-040.

24 Section 2 of the Commercial Pledges Act.

25 V. Kõve (see Note 7), pp. 246, 333.

26 Ibid., pp. 246, 333 . 
Court judgements dealing with the issue of whether the extent of the commercial pledge encompasses vehicles $^{{ }^{*} 27}$ and whether a notarised commercial-pledge agreement qualifies as an enforcement document ${ }^{* 28}$.

Although ambiguity related to the exact extent of the pledge is said to cause problems to creditors ${ }^{{ }^{*} 29}$ and, according to the Supreme Court, it is not possible to initiate enforcement proceedings under the commercial-pledge agreement, it has not prevented increasing use of the commercial pledge by creditors. Whether the cause is the aftermath of the financial crisis and creditors ' need for greater protection, however illusionary, or other, unknown factors, the registration of commercial pledges has increased in recent years, from 5,014 pledges in 2008 to 7,081 pledges in $2012^{*} 30$ and then 17,086 in $2015^{*}{ }^{31}$. For a comparison of magnitude, the corresponding number for Latvia was 144,976 in January $2010^{*} 32$.

How extensive the scope of the business pledge should be depends on many elements, all of which the legislator needs to consider. The first is limitations on the circle of persons entitled to grant a general pledge - should it consist of only companies or cover individuals also? For example, in the United States a general security right can be granted both by companies and individuals. Second is a limitation on the beneficiaries of a business pledge. In Belgium, only credit institutions were allowed to take a pledge over business, a limitation that was lifted by amendments to the law adopted in $2013^{*} 33$. Thirdly, one should consider whether the business pledge is the only possibility for having a non-possessory pledge over certain assets or other non-possessory pledges are available too. If so, what is their legal certainty? Fourthly, what is the ranking system under the relevant insolvency law, and how many preferential creditors does the insolvency law list?

\section{Protection of third parties}

\subsection{Publicity}

The EBRD core principles for a secured-transactions law contain a suggestion that there should be a possibility of publicising the existence of any security right. In the case of non-possessory security rights, this should be done via a public registry or notification system ${ }^{*} 34$.

For what purpose is it necessary to publicise who has pledged something, what and when, and to whom? Publicity of any existing security right and information on retention of title is necessary from the perspective of creditors, bona fide buyers, bailiffs, and bankruptcy administrators. From the perspective of creditors, publicity mitigates the risk of debtors' false wealth that could result in providing of unjustified credit - meaning that the debtor appears to possess many assets, while in reality most of them have been encumbered with security rights or sold to third parties, leaving the assets with minimal or no value ${ }^{*} 35$. Registration and publicity of encumbrances and retentions of title also minimises the risk of priority and validity disputes (e.g., fraudulent security agreements fabricated right before bankruptcy is declared). It also helps bailiffs and bankruptcy administrators decide whether or not to acknowledge the validity of the security right ${ }^{*} 36$. According to the Estonian Code of Enforcement Procedure, a bailiff shall take a claim of

27 Supreme Court Civil Chamber ruling 3-2-1-133-13, of 11.12.2013 (in Estonian).

28 Supreme Court Civil Chamber ruling 3-2-1-1-14, of 12.3.2014 (in Estonian).

29 P. Varul et al. (see Note 6), p. 368.

30 M. Haamer. Kommertspandi ulatus ja roll tagatisena pankroti-ja täitemenetluses (Scope and Role of the Commercial Pledge as Security in Bankruptcy and Enforcement Proceedings), research paper. Tartu 2013, p. 6 (in Estonian).

31 Electronic correspondence. L. Merkulova (with the Centre of Registers and Information Systems) and Annemari Õunpuu, 23.3.2015 (in Estonian).

32 E. Lodzins, L. Krumina. Bank finance and regulation: Multi-jurisdictional survey: Latvia. Text available at http://www. ibanet.org/Document/Default.aspx?DocumentUid=23A9C27D-80E6-458B-8DFC-EE56563762E9 (most recently accessed on 22.3.2015).

33 E. Janssens. New law on security over movable assets: Significant impact on financing transactions. - Linklaters Newsletter 2013/May, p. 4. Text available at http://www.linklaters.com/pdfs/mkt/brussels/Newsletter_Security_over_movable_assets_January_2013.pdf (most recently accessed on 20.3.2015).

34 EBRD core principles for a secured transactions law, Principle 8.

35 P.R. Wood (see Note 3), p. 7-007.

36 Registration of security interests: Company charges and property other than land: A consultation paper, Law Commission Consultation Paper No. 164. London: The Stationery Office 2002, p. 26. The text of the consultation paper is available on the Internet via http://www.lawcom.gov.uk/. 
a security right holder into account upon distribution of revenue if the right of security is evident from a publicly reliable register or a contract on which the security right is based is authenticated by a notary ${ }^{*}{ }^{3}$. The same principle applies in the case of bankruptcy proceedings for which the Bankruptcy Act specifies that the validity of security rights entered in the land register, ship register; commercial-pledge register, or securities register is acknowledged without defence ${ }^{*} 3$.

In the absence of a general security-rights register and notice-filing, the existing regulation creates many problems, which can be illustrated by the example of a pledge on bank accounts or receivables. If the debtor has not fulfilled a tax obligation, the tax authority is entitled to seize the bank account of the debtor or order the bank to transfer the money from the debtor's bank account to the tax authority. The tax authority is also entitled to seize other proprietary rights ${ }^{*} 39$. Provided that the debtor has a pledge on the bank account in favour of the bank, in the absence of any publicity mechanism, the existence of said pledge is not transparent to third parties, including the tax authority. The priority between the seizure of the funds by the tax authority and the bank as the beneficiary under the account-pledge agreement should then be settled by means of court proceedings. Although in the Netherlands there is no general security-rights register, there is a possibility to use registration with the tax authority for publicity purposes. In order for the nonpossessory pledge to be effective against third parties, it must be registered with the tax office, for fixing the date of the agreement. Alternatively, the agreement has to be notarised ${ }^{*}{ }^{*}$.

Given that Estonia does not have a positive credit register, there is no retention-of-title register, and it is questionable whether asset-title registry data - such as those in the Traffic Registry - are public or not, Estonia is in need of a reform that would render the security-right system more transparent and predictable for creditors, the tax authority, bailiffs, and bankruptcy administrators, reducing unnecessary disputes over validity and priority of security rights.

\subsection{Priority - asset-title registries and notice-filing}

Over the years, asset-based financing (lending against receivables, inventory, equipment, and machinery) has increased, increasing also in turn, the need for a general security-rights registry creating transparency for lenders and third parties, instead of an incoherent system of non-registered fiduciary transfers and a multitude of specific asset-title registries ${ }^{*}{ }^{41}$. The UNCITRAL remarks that registries for security rights in movables that are based on the type of the asset (equipment, receivables, inventory, ships, etc.) - i.e., assettitle registries - usually developed not as a well thought-through system but as a 'piecemeal recognition of individual non-possessory security devices in movable assets" 42 .

In England and the United States, the mitigation of priority disputes for a creditor secured by the universal pledge is achieved by means of sophisticated use of universal security rights (floating charges or floating liens) in combination with negative pledge clauses ${ }^{*} 43$ and perfection ${ }^{*} 44$ of pledge rights in debtor-indexed general security-right registries. The United States notice-filing system and functional approach to security rights (as opposed to a form-based approach) are more advanced than the English floating and fixed charge

37 Täitemenetluse seadustik. - RT I 2005, 27, 198; RT I 05.03.2015, 5, §108 (4) (in Estonian). English text available at https:// www.riigiteataja.ee/en/eli/513032015003/consolide (most recently accessed on 20.3.2015).

38 Pankrotiseadus. - RT I 2003, 17, 95; RT I 21.06.2014, 20, \$103 (4) (in Estonian). English text available at https://www. riigiteataja.ee/en/eli/511072014018/consolide (most recently accessed on 20.3.2015).

39 Maksukorralduse seadus. - RT I 2002, 26, 150; RT I 17.03.2015, 10, §§ 130 (1) 4) and 131 (1) (in Estonian). English text available at https://www.riigiteataja.ee/en/eli/519032015001/consolide (most recently accessed on 20.3.2015).

40 P.R. Wood (see Note 3), p. 9-035.

41 N.O. Akseli. International Secured Transactions Law: Facilitation of Credit and International Conventions and Instruments. New York: Routledge 2011, p. 176 DOI: http://dx.doi.org/10.4324/9780203831618 .

42 UNCITRAL Legislative Guide on Secured Transactions (see Note 10), p. 154.

43 In the case of the English floating charge, previous or subsequent fixed security right over a specific property always takes priority over the universal floating charge. Hence, creditors often use a negative pledge clause as a contractual restriction to prevent the company from creating any other security right 'ranking in priority to, or equally with the floating charge over the things which the floating charge could cover' (S.B. Marsh, J. Soulsby. Business Law. Nelson Thornes 2002, p. 266). The negative pledge does not prevent the debtor from pledging his assets and thereby creating competing or preferential security rights. However, the breach of the clause may be an event of default resulting in the termination of the loan agreement and enforcement of the floating charge.

44 In Anglo-American jurisdictions, 'perfection' means that 'the security becomes effective against creditors of the debtor and the other third parties' and 'typically involves publicizing the security interest' (P.R. Wood (see Note 3), p. 7-001). 
system. The United States has a 'unitary' security right, regardless of the form of the transaction (retention of title or pledge), with the security right made effective against third parties via a notice-filing system ${ }^{*} 45$. Central registry systems have so far not been widespread in Europe. One of the European countries recently adopting amendments along the lines of the regime in the United States is Belgium, which made substantial amendments to its Civil Code in May 2013. In its new form, the law allows for a pledge over any movable asset (present and future, as a pool or separately), with the possibility of publicising the pledge either by taking possession of the asset or by registering the pledge in the central National Pledge Registry. Ranking and priority in this system depend on the date of filing or the date of taking possession (with the latter possibility considered to cause disputes) ${ }^{*} 46$.

In England, registered fixed charges have priority over the floating charge, meaning that a general pledge is always subordinated to a specific pledge. This is a risk that the general pledge holder has to take into account as inherent risk deriving from the nature of a general pledge and is therefore considered to be "part of the ordinary course of business" 47 - a risk that the Estonian legislator and the Supreme Court have so far often refused to see as a natural part of the commercial pledge. Said risk could be significantly mitigated if Estonia had a central register for retention of title and non-possessory pledges, together with a priority system making the priority dependent on the date of publicity notice in the central register. Of course, the system needs to be combined with the existing public registries, such as the Traffic Registry and the central securities register. All in all, a central register for pledges over movables would significantly improve the chances of a commercial pledge holder being able to react to breach of a negative pledge clause (a clause also used in Estonian banking practice).

\section{Enforcement}

The Supreme Court has found that a notarised commercial pledge agreement cannot be an enforcement instrument within the meaning of the term's usage in the Code of Enforcement Procedure. In order to enforce the pledge agreement and sell the assets, the creditor has to turn to the courts for the necessary approval. The main reason for limiting the out-of-court enforcement possibilities with the commercial pledge, in the view of the Court, is related to the floating nature of the pledge object. In the event of enforcement it would be unclear which assets are covered by the commercial pledge and subject to sale. Also, the debtor would have to bear the burden of disputing the rightfulness of enforcement, as the creditor does not need any pre-enforcement court approval ${ }^{*}{ }^{8}$. In practice, before the Supreme Court gave its view in 2014, creditors and debtors often concluded notarised agreements containing enforcement clauses without any indication from the notaries or lower-instance courts that these agreements would not qualify as enforcement documents ${ }^{*} 49$.

The UNCITRAL guide refers to the fact that negotiations with the debtor company on a debt-restructuring plan take place against the backdrop of the secured creditor's right to enforce the security right and initiate bankruptcy proceedings in the case of debtor default. Hence, when the enforcement right of the secured creditor is weak (entailing costly and time-consuming civil litigation to enforce the pledge agreement), the debtor is less likely to seek reorganisation solutions proactively and in the case of payment difficulties will stall as long as possible ${ }^{*}$. The EBRD Model Law on Secured Transactions emphasises that the right of enforcement relies first and foremost on self-help, meaning that the pledgee should have 'broad but

45 According to Law Commission Consultation Paper 164 (see Note 36), p. 11. The English Law Commission has underscored three main principles of the notice-filing system: '(1) filing is not necessarily in relation to a specific transaction, but is a notice that a person has taken or intends to take a non-possessory security over a designated asset or class of assets; (2) the secured party can file a notice to protect the security interest either before or after the security is created, with priority normally going back to the time of filing of the financing statement; (3) to reduce the burden of filing, transaction documents are not filed and particulars to be filed are kept to a minimum', as it is left 'to a searcher to get the information she wants from the company or charge' (Law Commission Consultation Paper 164, pp. 61-62).

46 E. Janssens (see Note 33), pp. 1-2.

47 Law Commission Consultation Paper 164 (see Note 36), p. 33.

48 Supreme Court Civil Chamber ruling 3-2-1-1-14, of 12.3.2014 (in Estonian).

49 P. Varul et al. (see Note 6), p. 373.

50 UNCITRAL Legislative Guide on Secured Transactions (see Note 10), p. 276. 
clearly defined rights' to sell the pledged property ${ }^{*}{ }^{51}$. The model law suggests that once 60 days have passed from delivering the enforcement notice to the debtor and registering the enforcement notice in the security registry, the security holder has the right to transfer title to the secured property by selling it ${ }^{*} 52$.

Common-law jurisdictions are more inclined to favour self-help remedies, while European jurisdictions require the enforcement to take place via a bailiff or by judicial pre-approval ${ }^{*} 53$. Following the lines of the EBRD suggestions and in conjunction with amendments adjusting the scope and registration of security over movable assets, Belgium adopted a simplified enforcement procedure in 2013. The essence of the enforcement is that in all cases of pledges over movables, the parties are free to determine in the security agreement the manner of enforcement, whether by sale, rental, or appropriation, with the debtor given 10 days ` prior notice. The agreement is not an enforcement document, and, hence, the practical issues of creditor access to assets in the case of a non-possessory pledge still remain ${ }^{*} 54$.

It is recommended that common European rules either introduce expedited proceedings for judicial pre-approval of enforcement or allow for some form of self-help. The Estonian Code of Civil Procedure has a specific procedure for actions for compulsory enforcement arising from registered security over movables. The procedure is given the title 'documentary proceeding', with the idea being that all facts in proof of the claim can be supported by documents ${ }^{*} 55$. However, it is questionable whether such proceedings qualify as 'expedited proceedings', since there is no indication in the law as to deadlines within which the court should proceed with the compulsory enforcement claim. The plaintiff is left dependent on the work load of the court and without predictability of how long the proceedings could take.

\section{Conclusions}

From its creation, in the early 1990s, the commercial pledge has been a controversial pledge in the Estonian system of security rights, and one can only agree with the claim that its true nature and functioning has not been properly understood and discussed. It is clear from the statistics that there is a growing need for a pledge covering the assets currently within the scope of the commercial pledge. Before considering any detailed issues pertaining to the pledge, the legislator should answer the fundamental question of the purpose the commercial pledge serves in the Estonian security-rights system, along with whether Estonia needs a universal pledge and, if so, what should be its scope.

The reform and any amendments to the commercial-pledge regulation cannot be looked at separately from the question of whether Estonia should have a central register for pledges on movables, similar to the registry system introduced in Belgium in 2013. Considering trends in financing and the international arena generally toward debtor-indexed central registries with e-filing systems that serve the purpose of transparency for all third parties (existing and potential creditors, bailiffs, and bankruptcy administrators), Estonia should follow the international lead and introduce a central register for pledges on movables, which should also include entries on retention of title. The central register would help to minimise double pledging of a given asset and minimise disputes over priority of security rights, as the priority would be dependent on the publicity date of the non-possessory security right. It should be considered whether the central register should be based on a notice-filing system and precisely what information it should contain on the security agreement.

The strength of any security right depends to a large extent on the possibilities for enforcing it. Therefore, the enforcement possibilities for pledges over movable assets should be reconsidered, with possible amendments to the documentary procedure that involve extending the scope of pledges for which it is available (if all pledges on movables are to be registered), along with setting of specific procedural deadlines in the Code of Civil Procedure.

\footnotetext{
EBRD Model Law on Secured Transactions, 1994.

Ibid., Articles 24-26.

53 A. Veneziano. A Secured Transactions' Regime for Europe: Treatment of Acquisition Finance Devices and Creditor's Enforcement Rights. - Juridica International 2008/1, p. 94.

54 E. Janssens (see Note 33), p. 2.

55 Tsiviilkohtumenetluse seadustik. - RT I 2005, 26, 197; RT I 31.12.2014, 5, §406 (in Estonian). English text available at https://www.riigiteataja.ee/en/eli/505022015002/consolide (most recently accessed on 23.3.2015).
} 